\title{
Analyses of chemical composition and gastroprotective and antinociceptive properties of Eugenia involucrate DC. leaves
}

Giovana Vechi, Adriana Campos, Roseane Leandra da Rosa, Karla Capistrano, Tailyn Zermiani, Fátima de Campos Buzzi, Sérgio Faloni de Andrade, Valdir Cechinel Filho*

Programa de Pós-Graduação em Ciências Farmacêuticas (PPGCF) - Núcleo de Investigações Químico-Farmacêuticas (NIQFAR) - Universidade do Vale do Itajaí (UNIVALI), Rua Uruguai, 458 - Centro - 88302-901 - Itajaí, Santa Catarina, Brazil.

\begin{tabular}{|c|c|}
\hline ARTICLE INFO & ABSTRACT \\
\hline Article history: & \multirow{5}{*}{$\begin{array}{l}\text { Eugenia genus has shown relevant therapeutic results as a medicinal plant, and that is why this study aimed to know } \\
\text { the chemical composition of E. involucrata leaves and its gastroprotective and antinociceptive potential. The leaves } \\
\text { were collected at two moments, January and July of } 2014 \text {. Leaves were macerated in methanol, resulting in Crude } \\
\text { Methanol Extracts (CME), denominated CME-jan and CME-jul. The extracts were partitioned with chloroform and } \\
\text { ethyl acetate. Phytochemical analysis was performed by conventional chromatographic techniques and the isolated } \\
\text { substances were analyzed by usual spectrometric techniques. The major substance isolated from the ethyl acetate } \\
\text { fraction was (-)-catechin and phytol from the chloroform fraction. The gastroprotective evaluation was performed } \\
\text { by the ulcer model induced by ethanol, and the extract reduced significantly the total damaged area and the area of } \\
\text { injury relative to the treatments with doses of } 125 \text { and } 250 \mathrm{mg} / \mathrm{kg} \text {, but the } 125 \mathrm{mg} / \mathrm{kg} \text { dose was more effective. The } \\
\text { antinociceptive activity was evaluated by the writhing test induced by acetic acid. Extract and fractions reduced the } \\
\text { nociception }\left(26.5 \text { to } 64.4 \% \text { at } 10 \mathrm{mg} / \mathrm{kg} \text { ). Chloroform fraction collected in July exhibited more pronounced effect }\left(\mathrm{DI}_{50}\right.\right. \\
\text { of } 2.33 \mathrm{mg} / \mathrm{kg} \text { ). }\end{array}$} \\
\hline Received on: $03 / 02 / 2017$ & \\
\hline d on: $25 / 03 / 2017$ & \\
\hline Available online: $29 / 04 / 2018$ & \\
\hline $\begin{array}{l}\text { Key words: } \\
\text { Eugenia involucrate, } \\
\text { antinociceptive activity, } \\
\text { catechin, phytol, } \\
\text { gastroprotection. }\end{array}$ & \\
\hline
\end{tabular}

\section{INTRODUCTION}

Since many years ago, plants have been employed with success to cure the more distinct ailments. Currently, modern medicinal chemistry is using new approaches and technologies that confirm the scientific evidence on the therapeutic efficacy of various medicinal plants, their isolated substances and derivatives (Filho, 2015; Alves, 2013; Cragg and Newman, 2013).

The genus Eugenia comprises several species that possesses relevant therapeutic properties. Eugenia involucrata, popularly known as cerejeira, cereja-do-Rio Grande or araçazeiro, is commonly found in the south of Brazil, is used in traditional medicine as infusions to treat infections, diarrhea, indigestion, and bleeding. However, it was not

\footnotetext{
${ }^{*}$ Corresponding Author

Valdir Cechinel Filho, Programa de Pós-Graduação em Ciências Farmacêuticas (PPGCF) - Núcleo de Investigações QuímicoFarmacêuticas (NIQFAR) - Universidade do Vale do Itajaí (UNIVALI), Rua Uruguai, 458 - Centro - 88302-202 - Itajai, Santa Catarina, Brazil. E-mail: cechinel@univali.br
}

found previous studies regarding the chemical and biological aspects of this plant (Carvalho, 2010; Lorenzi, 2002; Sausen et al., 2009).

The present study aimed to investigate the chemical composition of E. involucrata leaves and the gastroprotective and antinociceptive potential of its methanolic extract and ethyl acetate and chloroform fractions, as well to compare two different collects (summer and winter).

\section{MATERIAL AND METHODS}

\section{Plant material}

The leaves of E. involucrata were collected in two different moments, January and July of 2014, in the city of Itajaí-SC. The plant material was identified by Prof. Oscar Iza (UNIVALI) and a voucher specimen was deposited at the Barbosa Rodrigues Herbarium (Itajaí) under n ${ }^{\circ} 55283$.

\section{Phytochemical analysis}

Fresh leaves of E. involucrata were macerated at room temperature in methanol for 7 days. After, the extracts were 
concentrated by using a rotatory evaporator to obtain the crude methanolic extract of January (CME-Jan, yield $=5.63 \%)$ and July (CME-Jul, yield $=3.75 \%)$.

The extracts were partitioned with chloroform and ethyl acetate furnishing the respective fractions (CLF-Jan and CLF-Jul; EAF-Jan, EAF-Jul,) and submitted to conventional chromatography methods such as chromatography column (CC) and thin-layer chromatography (TLC). TLC was used to evaluate the chemical composition of studied plants. The following solvent systems were used: hexane: ethyl acetate (7:3) and chloroform: methanol (8:2) and revealed with the following specific reagents: sulfuric anisaldehyde for steroids, terpenoids and glycosides compounds and ferric chloride for phenolic compounds.

Part of the CLF-Jan (2.5 g) was subjected to CC over silica-gel (40 g) eluted with hexane: acetone gradient. Fractions of $10 \mathrm{~mL}$ were collected and evaluated by TLC, visualizing the spots by UV $(254 \mathrm{~nm})$ and reaction with sulfuric anisaldehyde heated at $100^{\circ} \mathrm{C}$. Subfraction $29-40(280 \mathrm{mg})$ was re-chromatographed as before, yielding new 36 subfractions, which were combined according to their TLC profiles furnishing $82 \mathrm{mg}$ of a nonpure compound, which was re-chromatographed again with $\mathrm{CC}$ flash over silica-gel (12 g) eluted with hexane: acetone (8:2). It was obtained $4 \mathrm{mg}$ of a pure oil, identified as phytol, by using mass spectrometry and comparison with literature data (Souza et al., 2012).

Part of the EAF-Jan ( $4.8 \mathrm{~g})$, was subjected to CC over silica-gel (80 g) and eluted with chloroform: methanol gradient. Fractions of $10 \mathrm{~mL}$ were collected and evaluated by TLC, visualizing the spots by UV (254 nm) and, ferric chloride $3 \%$. Subfraction 25-34 (150 mg) was re-chromatographed as before, given $72 \mathrm{mg}$ of a pure solid, identified as (-)-catechin by direct comparison with an authentic sample and spectral data (NMR) reported previously (Ayres et al., 2009).

\section{High-performance liquid chromatography (HPLC)}

HPLC analysis was realized to compare the seasonal variation, CME-Jan (summer) and CME-Jul (winter), in relation to the (-)-catechin and to define (fingerprint) the compounds present in the extracts.

A Shimadzu LC-20AT LC system (Shimadzu, Tokyo, Japan) was used, consisting of an SPD-M20A photodiode array detector, an SIL-20AHT autosampler and a software LC-Solution (Shimadzu, Tokyo, Japan). The samples were diluted in methanol at $1 \mathrm{mg} / \mathrm{ml}$. The injections of samples $(20$ $\mu \mathrm{L}$ ) were carried out on a C18 column (Luna Phenomenex, $250 \times$ $4.5 \mathrm{~mm}^{2} ; 0.5 \mu \mathrm{m}$ film thickness and $100 \mathrm{~A}$ ), conditioned at $35^{\circ} \mathrm{C}$. The mobile phase consisted of acetonitrile and ultra-pure water ( $\mathrm{pH} 2.5$, phosphoric acid) eluded in a gradient system (Table 1), monitored at $280 \mathrm{~nm}$.

\section{Pharmacological assays}

Acute gastric lesions induced by ethanol/HCl in mice

In this study, were used 30 femaleSwiss mice (25-50 g), provided by the Central Animal House of Universidade do Vale do Itajaí (UNIVALI - Itajaí, SC, Brazil), housed at room temperature of $22^{\circ} \pm 2^{\circ} \mathrm{C}$ with $12 \mathrm{~h}$ dark/ light cycle and received water and food ad libitum.
Table 1: Gradient system used in HLPC analyses at $280 \mathrm{~nm}$

\begin{tabular}{ccc}
\hline Time & Acetonitrile (\%) & Water* $(\%)$ \\
\hline 0 & 15 & 85 \\
25 & 35 & 65 \\
30 & 80 & 20 \\
32 & 15 & 85 \\
35 & 15 & 85 \\
\hline
\end{tabular}

*pH 2.5, phosphoric acid.

The animals were housed and cared for in accordance with the Federal Government legislation on animal care. The experiment was authorized by the Ethical Committee for Animal Care of the Universidade do Vale do Itajaí (process number 019/13).

The experiment was performed according to the previously described method (Mizui and Doteuchi, 1983), with some modifications. After $12 \mathrm{~h}$ of fasting, the animals were randomly divided into different groups of six animals each and pre-treated orally with cimetidine (positive control - $100 \mathrm{mg} / \mathrm{kg}$ ), vehicle (negative control - distilled water) and the CME-Jul at doses of 50,125 e $250 \mathrm{mg} / \mathrm{kg}$. All the treatments were administered by gavage.

One hour after treatment, all the animals received 0.1 $\mathrm{mL} / 10 \mathrm{~g}$ (body weight) of a $0.3 \mathrm{~mol} / \mathrm{L} \mathrm{HCl} / 60 \%$ ethanol solution (ethanol $/ \mathrm{HCl}$ ) to induce a gastric ulcer. Another hour later, the animals were sacrificed by cervical dislocation, and the stomachs removed and opened along the greater curvature. The stomachs were gently rinsed with water to remove the gastric contents and blood clots, for subsequent scanning. The images obtained were analyzed using specific "EARP" software to measure each lesion point. The results were expressed as total lesion area $\left(\mathrm{mm}^{2}\right)$ and relative lesion area $(\%)$.

\section{Acetic acid-induced writhing}

Abdominal constriction was induced by intraperitoneal injection of acetic acid $(0.6 \%)$, according to the procedure described previously (Collier et al., 1968) with minor modifications. Male Swiss mice (25-35 g) were pre-treated with CME-Jul and EAF-Jul $(10 \mathrm{mg} / \mathrm{kg})$ and CLF-Jul (10, 3 and $1 \mathrm{mg} / \mathrm{kg})$, intraperitoneally (i.p.), $30 \mathrm{~min}$ before acetic acid injection (six to eight animals in each group). The control animals received a similar volume of $0.9 \% \mathrm{NaCl}(10 \mathrm{ml} / \mathrm{kg}$, i.p.).

All the experiments were carried out at $23 \pm 2{ }^{\circ} \mathrm{C}$. After the challenge, pairs of mice were placed in separate glass funnels and the number of contractions of the abdominal muscles, together with stretching, were counted cumulatively over a period of 20 min. Antinociceptive activity was expressed as the reduction in the number of abdominal contractions between the control animals and the mice pretreated with the test materials.

\section{Statistics}

The data are reported as mean \pm standard error of the mean (SEM) and compared using one-way analysis of variance (ANOVA) followed by Dunnett's pairwise test. Values of $\mathrm{p}<0,05$ or less were considered significant. 


\section{RESULT AND DISCUSSION}

Preliminary studies by using TLC revealed with specific reactive including sulfuric anisaldehyde and ferric chloride, indicated the presence of steroids, terpenes and phenolic compounds as main constituents of this plant.

Fractionation chloroform and ethyl acetate fractions (plant collected in January) by column chromatographic permitted the isolation of phytol, an acyclic diterpene, and a phenolic compound, (-)-catechin (Figure 1). Although both compounds are common in plants, this is the first report from E. involucrata.

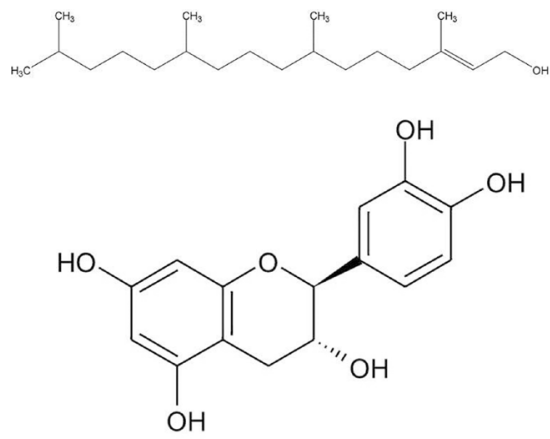

Fig. 1: The molecular structure of Phytol (a) and (-)-Catechin (b).

Considering the importance of the seasonality in the influence of secondary metabolism (Gobbo-Neto and Lopes, 2007), we have examined the chemical constitution of the plant collected in two seasons, summer and winter.
HPLC analysis showed the similarity of substances in the summer and winter extracts, but also important differences, such as the substances that have retention time in $\sim 7, \sim 10, \sim 14.5$ and $\sim 35$ minutes, that are visible in winter extract but doesn't appear in the summer or appear in fewer amounts. The isolated compound (-)-catechin is the major compound in both extracts, but apparently, the winter extract shows higher amounts (Figure 2).

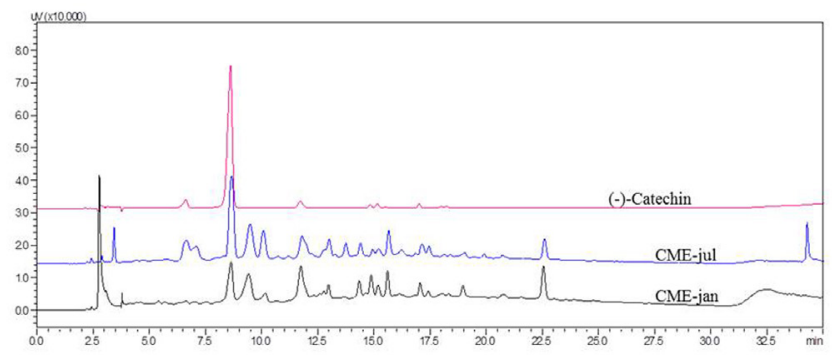

Fig. 2: HPLC analysis of CME-Jan, CME-Jul and (-)-Catechin from the leaves of $E$. involucrate.

The oral administration of CME-Jul extract to the mice significantly reduced the gastric injury caused by administration of the ethanol/HCl solution compared to the control group (vehicle). The doses of 125 and $250 \mathrm{mg} / \mathrm{kg}$ reduced significantly the total lesion area $\left(\mathrm{mm}^{2}\right)$ and relative lesion area (\%) when compared to the negative control, while the dose of $50 \mathrm{mg} / \mathrm{kg}$ did not show significance. As expected, in the positive control group, treated with cimetidine, it was observed a significant gastroprotective effect (Table 2).

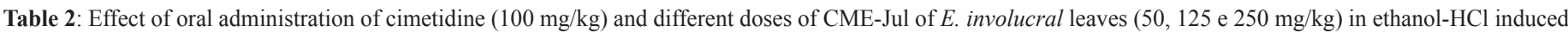
ulcer in mice $(n=6)$.

\begin{tabular}{|c|c|c|c|}
\hline Treatment & Dose (mg/kg) & Total lesion area $\left(\mathrm{mm}^{2}\right)$ & Relative lesion area $(\%)$ \\
\hline Control & Vehicle & $42.86 \pm 10.60$ & $10.57 \pm 3.61$ \\
\hline CME-jul & 50 & $23.76 \pm 5.63$ & $6.31 \pm 1.96$ \\
\hline of & 125 & $4.61 \pm 2.03 * *$ & $1.21 \pm 0.56^{*}$ \\
\hline E. involucrata & 250 & $6.67 \pm 1.81 * *$ & $2.13 \pm 0.54^{*}$ \\
\hline Cimetidine & 100 & $1.98 \pm 0.44 * *$ & $0.75 \pm 0.17^{* *}$ \\
\hline
\end{tabular}

Significant difference in relation to the control group $\left(* * \mathrm{p}<0,01\right.$ and $\left.{ }^{*} \mathrm{p}<0,05\right)$, ANOVA, expressed as mean \pm SEM, a posteriori test of Dunnett.

The model of gastric lesion induced by ethanol mimics one of the main causes of the gastric ulcer and gastritis in humans, the excessive use of alcoholic drinks. The administration of ethanol acidified provokes extensive areas of necrosis and hemorrhage in the gastric mucosa, which proves the toxicity of this agent. The ethanol toxicity changes the gastric cell homeostasis and damages the tissue, beyond increasing formation of free radicals and reactive oxygen species (Basting et al., 2014).

Antioxidants have the power to control free radicals, and many secondary metabolites of plants have this property, such as phenolic compounds and terpenoids (Klein-Júnior et al., 2012).

Other Eugenia species studied previously showed gastroprotective properties, such as E. umbelliflora (Meyre-Silva et al., 2009), E. punicifolia (Basting et al., 2014) and E. jambolana (Donatini et al., 2009). In general, the activity can be related to the presence of tannins, flavonoids, and terpenes, which were the main class of substances evidenced in the leaves of E. involucrata. In this mode, the present study pointed that, as well as other Eugenia species, the E. involucrata presents gastroprotective potential.

To determine a possible antinociceptive effect for this plant, the writing test was selected, which is common in trials, because of its simplicity, reproducibility e low cost, showing good relation to the pre-clinic and clinic studies (Calixto et al., 2000; Campos-Buzzi et al., 2006).

The results of the evaluation of CME-Jul, CLF-Jul, and EAF-Jul at a dose of $10 \mathrm{mg} / \mathrm{kg}$ indicated that all the samples tested significantly reduced the nociception, but a greater result was observed for the non-polar fraction, CLF-Jul (64.4\%) (Figure 3).

Common drugs used in clinical treatments, such as aspirin and paracetamol, show inhibition around $35 \%$ in same conditions 
(Costa et al., 2007). After this trial result, it was determined the $\mathrm{DI}_{50}$ (minimal dose able to inhibit $50 \%$ of writhings compared to the control group) of CLF-Jul (Figure 4).

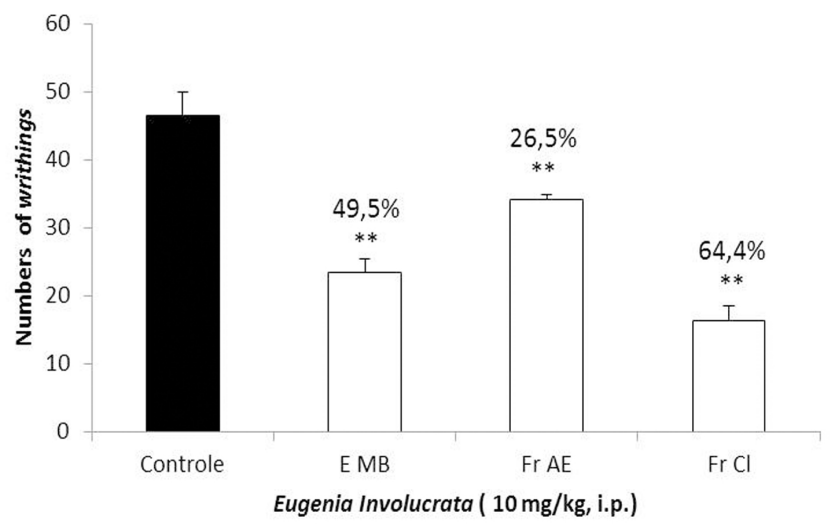

Fig. 3: Inhibition of CME-Jul, CLF-Jul, and EAF-Jul of the leaves of E. involucrata, at a dose of $10 \mathrm{mg} / \mathrm{kg}$ (via i.p.) in the model of acetic acid-induced writhing in mice $(n=6)$.

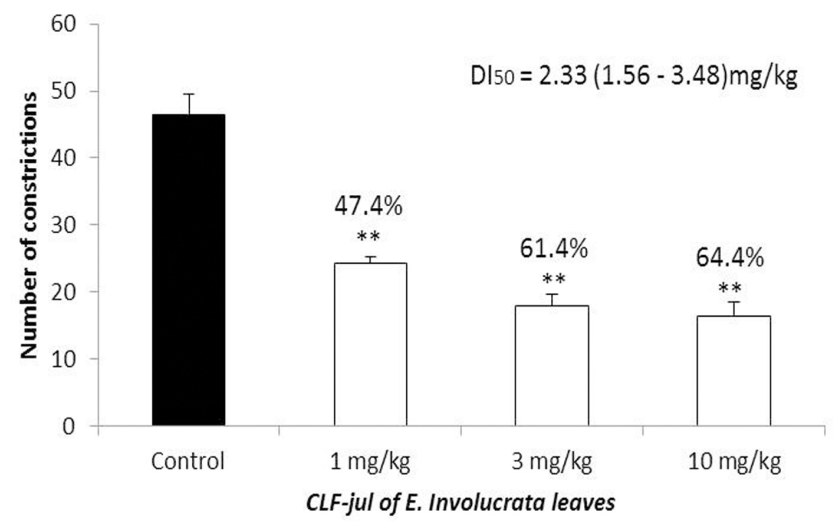

Fig. 4: Inhibition of the chloroform fraction (CLF-Jul) leaves of E. involucrata, at doses of 1,3 and $10 \mathrm{mg} / \mathrm{kg}$ (via i.p.) in the model of acetic acid-induced writhing in mice $(n=6)$.

All the tested doses showed significant reduction of writhings, and the $\mathrm{DI}_{50}$ was about $2 \mathrm{mg} / \mathrm{kg}$. Comparing to the same drugs mentioned before, that exhibited a $\mathrm{DI}_{50}$ around $25 \mathrm{mg} / \mathrm{kg}$ (Serafin et al., 2007), CLF-Jul was about 25-fold more potent than these drugs.

The antinociceptive potential was evidenced previously in leaves of other Eugenia species, such as E. fruticosa (ShamsUd-Doha et al., 2012) and E. punicifolia (Basting et al., 2014).

Antinociceptive potential was evidenced previously in leaves of other Eugenia species, such as E. fruticosa (Shams-UdDoha et al., 2012) and E. punicifolia (Basting et al., 2014).

Terpenes present pronounced analgesic potential and they can act in different pathways (Calixto et al., 2000; Guimarães et al., 2013; Niero and Malheiros, 2014). The presence of terpenes in the chloroform fraction of E. involucrata leaves can, therefore, to explain, at least in part, its potent antinociceptive action.

\section{CONCLUSION}

In conclusion, E. involucral leaves showed gastroprotective and antinociceptive potential, related to the terpenes and phenolic compounds. However, the studies are in progress to confirm these results in other specific models as well as to isolate the minor constituents of this plant.

\section{ACKNOWLEDGMENTS}

The authors are grateful to CNPq, FAPESC-SC, and UNIVALI for their financial support.

\section{REFERENCES}

Alves LF. Produção de Fitoterápicos no Brasil: história, problemas e perspectivas. Rev Virtual Quím. 2013; 5:450-513.

Ayres MCC, Chaves MHRinaldo D, Vilegas W, Vieira Júnior GM. Constituintes químicos e atividade antioxidante de extratos das folhas de Terminalia fagifolia Mart. et Zucc. Quím Nova. 2009; 32:1509-1512.

Basting RT, Nishijima CM, Lopes JA, Santos RC, Lucena Périco L, Laufer S, Bauer S, Costa MF, Santos LC, Rocha LR, Vilegas W, Santos AR, Dos Santos C, Hiruma-Lima CA. Antinociceptive, anti-inflammatory and gastroprotective effects of a hydroalcoholic extract from the leaves of Eugenia punicifolia (Kunth) DC. in rodents. J Ethnopharmacol. 2014; 157:257-267.

Campos-Buzzi F, Campos JP, Tonini PP, Corrêa R, Yunes RA, Boeck P, Cechinel Filho V. Antinociceptive effects of synthetic chalcones obtained from xanthoxyline. Arch Pharm. 2006; 339:361-365.

Calixto JB, Beirith A, Ferreira J, Santos ARS, Cechinel Filho $\mathrm{V}$, Yunes RA. Naturally occurring antinociceptive substances from plants. Phytother Res. 2000; 14:401-418.

Carvalho PER. 2010. Espécies arbóreas brasileiras. Brasília, DF: Embrapa: informação tecnológica; Colombo: Embrapa Florestas.

Cechinel Filho V. 2015. Medicamentos de origem vegetal. Itajaí, Brazil: UNIVALI Editora.

Collier HO, Dinneen LC, Johnson CA, Schneider C. The abdominal constriction response and its suppression by analgesic drugs in the mouse. $\mathrm{Br}$ J PharmacChemother. 1968; 32:295-310.

Costa BBC, Corrêa R, Souza MM, Preto JB, Ardenghi JV, Campos-Buzzi F, Cechinel Filho V. Antinociceptive effects of tetrahydrophtalamides and related compounds. Z Naturforsch. 2007; 62:201-206.

Cragg GM, Newman DJ. Natural products: a continuing source of novel drug leads. Biochim Biophys Acta. 2013; 1830:3670-3695.

Donatini RS, Ishikawa T, Barros SBM, Bacchi EM. Atividades antiúlcera e antioxidante do extrato de folhas de Syzygium jambos (L.) Alston (Myrtaceae). Rev Bras Farmacogn. 2009; 19:89-94.

Gobbo-Neto L, Lopes NP. Plantas medicinais: fatores de influência no conteúdo de metabólitos secundários. Quím Nova. 2007; 30:374-381.

Guimarães AG, Quintans JSS, Quintans JUNIOR LJ. Monoterpenes with analgesic activity - a systematic review. Phytother Res. 2013; 27:1-15.

Klein-Júnior LC, Santin JR, Niero R, Andrade SF, Cechinel Filho $\mathrm{V}$. The therapeutic lead potential of metabolites obtained from natural sources for the treatment of peptic ulcer. Phytochem Rev. 2012; 11:567-616.

Lorenzi H. 2002. Árvores brasileiras: manual de identificação e cultivo de plantas arbóreas nativas do Brasil. 4nd ed. Nova Odessa: Instituto Plantarum.

Meyre-Silva C, Petry CM, Berté TE, Becker RG, Zanatta F, Delle-Monache F, Cechinel Filho V, Andrade SF. Phytochemical analysis and gastroprotective effects of Eugenia umbelliflora (Myrtaceae) on experimental gastric ulcers. Nat Prod Comm. 2009; 4:1-6.

Mizui T, Doteuchi M. Effect of polyamines on acidified ethanolinduced gastric lesion in rats. Jpn J Pharmacol. 1983; 33:939-945.

Niero R, Malheiros A. Triterpenos e sua importância químicomedicinal. In: Yunes RA, Cechinel FilhoV. eds. Química de produtos naturais, novos fármacos e a moderna farmacognosia. Itajaí: UNIVALI. 2014. 496p. 
Sausen TL, Lowe TR, Figueiredo LS, Buzatto CR. Avaliação da atividade alelopática do extrato aquoso de folhas de Eugenia involucrata DC. e Accasellowiana (O. Berg) Burret. Polibotánica [online]. 2009; 27:145-158.

Serafin C, Nart V, Malheiros A, Souza MM, Fischer L, Delle Monache G, Delle Monache F, Cechinel Filho V. Bioactive phenolic compounds from aerial parts of Plinia glomerata. Z Naturforsch. 2007; 62:196-200

Shams-Ud-Doha KM, Akter M, Al Mahmud Z, Apu AS, Howlader MA. Antinociceptive activity of the methanol extracts of leaves of Eugenia fruticosa (Roxb.) and Glycosmispentaphylla (Retz.) in Swiss albino mice. JAPHAC. 2012; 2:99-102.
Souza LGS, Almeida MCS, Monte FJQ, Santiago GMP, BrazFilho R, Lemos TLG, Gomes CL, Nascimento RF. Constituintes químicos de Capraria biflora (Scrophulariaceae) e atividade larvicida de seu óleo essencial. Quím Nova. 2012; 35:1-8.

\section{How to cite this article:}

Abas FZ, Zakaria ZA, Ani FN. Analyses of chemical composition and gastroprotective and antinociceptive properties of Eugenia involucrate DC. leaves. J App Pharm Sci, 2018; 8(04): 079-083. 